\title{
Human papillomavirus detection in moroccan patients with nasopharyngeal carcinoma
}

\author{
Nadia Laantri ${ }^{1,2}$, Mohammed Attaleb ${ }^{3}$, Mostafa Kandil $^{2}$, Fadwa Naji', Tarik Mouttaki ${ }^{1}$, R'kia Dardari ${ }^{1}$, \\ Khalid Belghmi ${ }^{4}$, Nadia Benchakroun ${ }^{5}$, Mohammed El Mzibri ${ }^{3}$, Meriem Khyatti ${ }^{*}$
}

\begin{abstract}
Background: Nasopharyngeal carcinoma (NPC) is a malignant tumor which arises in surface epithelium of the posterior wall of the nasopharynx. There's is evidence that Epstein Barr virus (EBV) is associated to NPC development. However, many epidemiologic studies point to a connection between viral infections by the human papillomavirus (HPV) and NPC.

Method: Seventy Moroccan patients with NPC were screened for EBV and HPV. EBV detection was performed by PCR amplification of BZLF1 gene, encoding the ZEBRA (Z Epstein-Barr Virus Replication Activator) protein, and HPV infection was screened by PCR amplification with subsequent typing by hybridization with specific oligonucleotides for HPV types 16, 18, 31, 33, 35, 45 and 59.

Results: The age distribution of our patients revealed a bimodal pattern. Sixty two cases (88.9\%) were classified as type 3 (undifferentiated carcinoma), 6 (8.6\%) as type 2 (non keratinizing NPC) and only 2 (2.9\%) cases were classified as type 1 (keratinizing NPC). EBV was detected in all NPC tumors, whereas HPV DNA was revealed in 34\% of cases (24/70). Molecular analysis showed that 20.8\% (5/24) were infected with HPV31, and the remaining were infected with other oncogenic types (i.e., HPV59, 16, 18, 33, 35 and 45). In addition, statistical analysis showed that there's no association between sex or age and HPV infection $(P>0.1)$.

Conclusion: Our data indicated that EBV is commonly associated with NPC in Moroccan patients and show for the first time that NPC tumours from Moroccan patients harbour high risk HPV genotypes.
\end{abstract}

\section{Background}

Nasopharyngeal carcinoma (NPC) is a tumour that arises in the epithelium surface of the posterior nasopharynx, and shows a peculiar geographic and ethnic distribution. The highest incidence rates of NPC are found among the southern Chinese population and in isolated northern populations such as Eskimos and Greenlanders (30 to 80 cases per 100,000 per year [1]. Intermediate incidence ( 8 to 12 cases per 100,000 per year) was reported in the Mediterranean basin, especially among the Arabic populations of North Africa (7-10\% of all cancers among men), where NPC is also the commonest tumour of the ear, nose and throat region $[2,3]$. The etiology of NPC seems to be multifactorial with evidence that genetic, viral and other environmental factors are involved together or separately, simultaneously or consecutively [4].

\footnotetext{
* Correspondence: meriem.khyatti@pasteur.ma

'Laboratory of Oncovirology, Institut Pasteur du Maroc, 1 Place Louis Pasteur, 20360 Casablanca, Morocco

Full list of author information is available at the end of the article
}

Retrospectives and prospectives epidemiologic studies have indicated the association between Epstein-Barr virus (EBV), an ubiquitous human herpesvirus, and the development of different malignancies, such as Burkitt's lymphoma, 40\%-50\% of Hodgkin's disease, B-cell lymphoma in immunocompromised individuals, and NPC $[4,5]$. Undifferentiated NPC is one of the most striking examples of human malignancies that have been found strongly associated with the EBV, and interest in human papillomavirus (HPV) as a cofactor in NPC occurrences has emerged over the last few years [6].

The papillomaviruses are small double-stranded DNA viruses which infect squamous epithelia and display a very high selectivity for the specific epithelium infected [7,8]. More than 100 different HPV genotypes have been described, but only 30 genotypes identified in the female genital tract are associated with epithelial neoplasms ranging from benign common warts to malignant carcinoma of the uterine cervix [9]. It is widely reported that in addition to HPV 16 and 18, which are frequently 
found in association with cervical cancer (CC), HPVs 31, $33,35,39,45,51,52,56,58,59,68,73$ and 82 , while other three as probable high-risk types (types 26, 53, and 66) are also considered as carcinogenic [10].

According to their ability to transform epithelial cells, HPV genotypes are divided into low-risk and high-risk types. Low-risk types are associated with benign lesions such as warts, while infections with high-risk types progress to malignant lesions [8-10]. It has been suggested that normal human oral epithelial cells, especially nasopharyngeal cells, could be very susceptible to persistent HPV and EBV co-infections and that EBV and high-risk HPV co-infections may play an important role in the initiation of a neoplastic transformation of human oral epithelial cells [11]. To date, different degrees of associations between HPV and NPC have been described, yet no conclusive data have been obtained. Given the particular characteristics of NPC in the Moroccan population in terms of incidence, age distribution and the predominance of specific EBV strains, we hypothesize that NPC tumours from Moroccan patients harbour a specific HPV genotype. To our knowledge, this is the first study to address the question of HPV implication as a pathogenetic cofactor in NPC patients from North Africa, and the benefit of any additional knowledge that can be used for detection cannot be overemphasized.

\section{Results}

The demographic characteristics of the 70 patients showed that the mean age of patients was 39.65 with extreme ages at 10 and 87 years old. The age distribution of our patients is represented in Figure 1 and revealed a bimodal pattern. The first and second peak correspond respectively to 11-20 and 51-60 years ranges. The male-to-female ratio was 2.33 to 1 .

The pathological analysis was performed according to the World Health Organization (WHO) classification and revealed that among the 70 cases, 62 (88.9\%) were classified as type 3 (undifferentiated carcinoma), 6 $(8.6 \%)$ as type 2 (non-keratinizing NPC) and only 2 (2.9\%) cases were classified as type 1 (keratinizing NPC) (Table 1).

The presence of amplifiable DNA, using primers for a fragment of $\beta$-globin gene, was confirmed for all cases and all DNA samples were adequate for further analysis. Our results show that although all NPC biopsies were EBV positive, HPV testing revealed the presence of HPV DNA in $34 \%$ of NPC cases (24/70) (Table 1).

The distribution of HPV DNA in the $24 \mathrm{HPV}$ positive NPC cases is reported in (Table 1). Molecular analysis showed that HPV31 was the most common subtype and was present in $20.8 \%$ of HPV positive cases (5/24) and HPV59 in $16.7 \%(4 / 24)$, whereas the other high risk HPV 16, 18, 33, 35 and 45 were present in $8.3 \%(2 / 24)$, $8.3 \%(2 / 24), 4.2(1 / 24), 4.2(1 / 24)$ and $4.2(1 / 24)$ respectively.

Distribution of HPV genotypes according to the anatomy pathology status showed that among the 62 NPC type III, 22 were HPV positive with a predominance of HPV31 which was present in $22.7 \%$ of cases $(5 / 22)$, whereas, the only HPV-positive NPC type II biopsy was $\mathrm{HPV}-18$ positive and the only HPV positive NPC type I was HPV-33 positive.

No statistically difference was observed in the HPV prevalence between males (34.7\%) and females (33\%) (Table 2), and no correlation between age and HPV status was found (Table 3). The mean age of HPV-positive

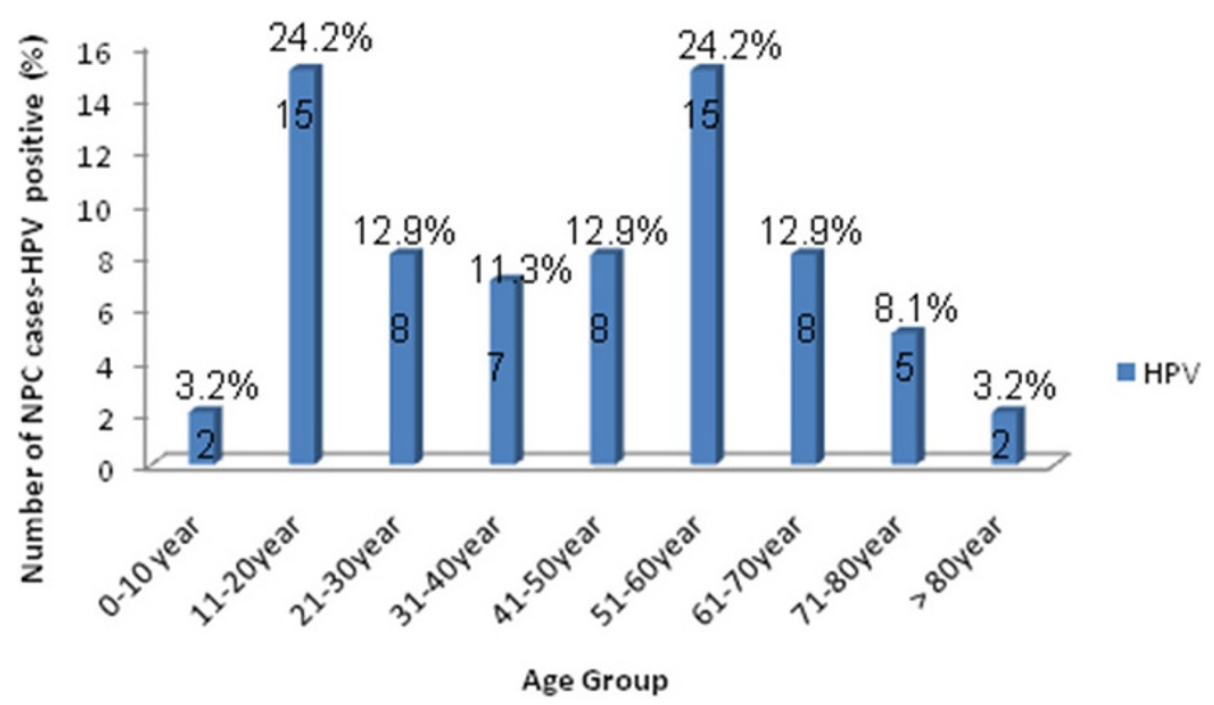

Figure 1 Distribution of patients with NPC according to their age. For each age range, number of cases and percentage are given. 
Table 1 Distribution of EBV and HPV infection in NPC cases

\begin{tabular}{lccccccccccc}
\hline NPC cases & N & EBV+ & HPV+ & HPV $\mathbf{1 6}$ & HPV $\mathbf{1 8}$ & HPV $\mathbf{3 1}$ & HPV $\mathbf{3 3}$ & HPV $\mathbf{3 5}$ & HPV $\mathbf{4 5}$ & HPV 59 & Untyped HPV cases \\
\hline NPC type I & 2 & 2 & 1 & & & & 1 & & & & \\
\hline NPC type II & 6 & 6 & 1 & & 1 & & & & & \\
\hline NPC type III & 62 & 62 & 22 & 2 & 1 & 5 & & 1 & 1 & 4 & 8 \\
\hline Total & 70 & 70 & 24 & 2 & 2 & 5 & 1 & 1 & 1 & 4 & 8 \\
\hline
\end{tabular}

$\mathrm{N}$ : Number of patients.

patients was 37.3, whereas the mean age of HPV-negative cases was 43.0 years $(\mathrm{P}>0.1)$.

\section{Discussion}

It is widely accepted that EBV is etiologically associated with NPC; but it is proven that other co-factors might be involved in the carcinogenesis process. HPVs are considered to be one of those factors since they possess the ability to transform epithelial cells and a significant number of NPC biopsies harbour HPV DNA [12,13]. We report here that 34\% (24/70) from Moroccan NPC biopsies harbour HPVs. These results are in agreement with other studies reporting the same prevalence of HPV DNA in NPC cases. In fact, using the same consensus primers, HPV DNA was detected in 31 of 103 NPC samples (30\%) [8]. Moreover, Krishna et al. have shown that HPV DNA was detected in $38.8 \%$ of 36 southern Indian NPC cases [14]. Tung et al. in Eightyeight fresh tissue samples of NPC showed that HPV DNA was detected in $51 \%$ of the specimens [15].

Coinfection by HPV and EBV has not been well documented and the significance of the presence of both viruses in nasopharyngeal cells has not been determined. In our study, coinfection with both viruses was observed in $34 \%$ of patients. Tung et al. showed that among 88 fresh NPC specimens from Chinese population, coexistence of EBV and HPV DNA was observed in $42 \%$ of samples [15].

Of interest, EBV was detected also in CC specimens from Indonesian patients, and $68 \%$ of analysed cases are co-infected with HPV and EBV [16]. In our study, HPV and EBV co-infection seems to be less frequent in NPC. Theses differences may be due to the population' characteristics and the dissemination power of HPV in the population.

Our results show no correlation between HPV status with either age or gender in NPC patients. These

Table 2 Comparison of HPV positive cases between Male and Female

\begin{tabular}{llcc}
\hline Patients & N & HPV positive & P - value \\
\hline Male & 49 & 17 & 0.869 \\
\hline Female & 21 & 7 & \\
\hline
\end{tabular}

$\mathrm{N}$ : Number of patients. findings are supported by other studies that reported no significant differences $[17,18]$. However, Zhang et al. showed that HPV infection either in oral squamous cell carcinoma or normal mucosa was observed with a higher frequency in men $(81.3 \%)$ compared with that in women $(60 \%)$ [19]. to evaluate the association between HPV status and, age and/or gender, in NPC cases, a study with a large sampling is needed.

With regard to HPV genotypes, HPV31 was the most frequent genotype in Moroccan NPC patients (20.8\%). The same genotype was also frequently found in tonsils and nasopharyngeal cells in western Mexico NPC cases [20]. The second prevalent HPV type detected in our NPC biopsies is HPV59 (16,7\%). Of interest, HPV-16 and -18, which are the most virulent genotypes associated with CC in Moroccan woman (35\% to $45 \%$ ) $[21,22]$, were detected in very few Moroccan NPC cases $(8.3 \%)$, and similar data were reported in an Iranian study [23].

Geographic and racial distinctions have been identified between NPC of the Far East versus those diagnosed in Caucasian American patients with regard to the interrelationship of histologic subtype and HPV infection. In fact, HPV are detected more often (50\%) in type I NPC from American Caucasian patients than type III [6]. In our study, one of two WHO-I and 22 of 68 WHO-II/III NPCs tumors were HPV positive. The very low number of NPC type-I cases available for comparison, reflecting the rarity of WHO-I tumors in NPC patients from Morocco, did not allow us to evaluate the relationship between HPV and NPC histologic subtype.

Taken together, these data suggest that i) HPV genotypes associated with NPC are different from those consistently found in CC and ii) the HPV genotypes associated with NPC are not geo-specific.

HPV and EBV co-infections have not been well documented and the significance of the presence of

Table 3 Comparison of age between HPV-positive and HPV-negative cases

\begin{tabular}{llll}
\hline HPV infection & $\mathbf{N}$ & Mean age & P - value \\
\hline HPV positive cases & 24 & 37.3 & 0.425 \\
\cline { 1 - 2 } HPV negative cases & 46 & 43.0 & \\
\hline
\end{tabular}

$\mathrm{N}$ : Number of patients. 
both viruses in nasopharyngeal cells has not been determined. It has been shown that ZEBRA, an EBV immediate early protein expressed during lytic replication that activates early EBV genes, binds to p53 [24]. The physical interaction of the ZEBRA and p53 protein prevents $\mathrm{p} 53$ from activating p53-responsive promoters $[25,26]$. Similarly, HPV has been found to interact with $\mathrm{p} 53$, suggesting that this interaction promotes cell growth and thereby enhance viral replication [27]. Targeting p53 may be a common requirement for the replication of many types of DNA viruses [16]. In addition, B cells transfected with EBV latent membrane protein lost the regulatory effects of the retinoblastoma (RB) protein, and the HPV E7 transcript has been shown to immunoprecipitate the $R B$ protein [28]. Thus, the functional loss of the RB protein might be one event common to both the HPV and EBV carcinogenic pathways. Further investigations to evaluate the expression of viral genes, especially the E6 and E7 oncogenes, are necessary to identify the possible role of HPV infection in NPC development. These investigations could lead to the development of screening programs, new therapeutic approaches and specific methods of prevention, especially in high incidence areas.

On the other hand, further studies to evaluate the impact of EBV and HPV coinfection in cervical and nasopharyngeal carcinogenesis and molecular mechanisms implicated in tumor development are warranted.

\section{Materials and methods Samples}

The analyses were performed on biopsies collected from 70 patients with histopathologically confirmed NPC at the Oncology Centre in Casablanca, Morocco, after informed written consent, as approved by the local Ethical Committee. The biopsies were stored at $-80^{\circ} \mathrm{C}$ until used.

\section{DNA extraction}

DNA extraction was performed on frozen biopsy material. The frozen tissues were homogenized and lysed in digestion buffer $(50 \mathrm{mM}$ Tris- $\mathrm{HCl}, \mathrm{pH} 8.5 ; 1 \mathrm{mM}$ EDTA and $0.5 \%$ Tween-20) containing $200 \mu \mathrm{g} \mathrm{ml}^{-1}$ of proteinase $\mathrm{K}$. The samples were digested for $3 \mathrm{~h}$ at $55^{\circ} \mathrm{C}$. Proteinase $\mathrm{K}$ was heat-inactivated at $95^{\circ} \mathrm{C}$ for 15 min. The samples were spin down and the supernatants were collected and stored at $-20^{\circ} \mathrm{C}$ until used. In order to evaluate the efficiency of DNA extraction, all samples were polymerase chain reaction (PCR)-amplified using PC04 and GH20 primers specific for human $\beta$-globin gene (Table 4).

\section{PCR-quality control}

To avoid contamination leading to false positive results, all PCR-related work was carried out in specialized zones within a PCR laboratory that undergoes UV purification at least once every $24 \mathrm{~h}$. To detect crossover contamination negative controls (PCR reagents containing no DNA) were included in each PCR amplification. All negative controls were negative for $\beta$-globin and HPV assay. Positive controls containing the $\mathrm{SiHa}$ and Caski cell lines always amplified $\beta$-globin and HPV DNA, respectively.

\section{EBV Testing}

Z-Epstein-Barr Virus Replication Activator (ZEBRA) gene was amplified by PCR using ZES (forward) and ZEAS (reverse) primers [29]. Primer sequences are reported in Table 4 . Briefly, $2 \mu \mathrm{L}$ of DNA were subjected to $\mathrm{PCR}$ in a total volume of $50 \mu \mathrm{L}$, which includes $5 \mu \mathrm{L}$ of Taq DNA polymerase buffer, $50 \mathrm{pM}$ of ZES/ ZEAS primer mix, $0.2 \mu \mathrm{M}$ of each dNTP (dATP, dCTP, dGTP and dTTP), and 2.5 units of Taq DNA polymerase (Promega Corp., Madison, WI). Samples were denatured at $95^{\circ} \mathrm{C}$ for $5 \mathrm{~min}$, then cycled 30 times through $1 \mathrm{~min}$ denaturation at $95^{\circ} \mathrm{C}, 2 \mathrm{~min}$ annealing at $58^{\circ} \mathrm{C}$ and 2 min extension at $72^{\circ} \mathrm{C}$. A final extension of $7 \mathrm{~min}$ at $72^{\circ} \mathrm{C}$ was performed. The final PCR products were analyzed by electrophoresis through a $1 \%$ agarose gel stained by ethidium bromide and optically visualized by ultraviolet transillumination.

\section{HPV testing}

DNA samples were amplified by PCR using consensus primers MY09 and MY11 for a 450 bp target sequence in the L1 region that is highly conserved on a broad spectrum of HPV genotypes [29]. Each reaction mixture of $50 \mu \mathrm{l}$ contained $50 \mathrm{pM}$ of each primer, $0.2 \mu \mathrm{M}$ of each dNTP (dATP, dCTP, dGTP and dTTP), 0.625 units of Taq DNA polymerase (Amersham Biosciences, Little Chalfont, UK), and $3 \mu \mathrm{L}$ of DNA in Taq DNA polymerase buffer. The mixture was first denatured at $94^{\circ} \mathrm{C}$ for $7 \mathrm{~min}$, then cycled 35 times through $30 \mathrm{~s}$ denaturation at $94^{\circ} \mathrm{C}, 1 \mathrm{~min}$ annealing at $52^{\circ} \mathrm{C}$ and $1 \mathrm{~min} 30 \mathrm{~s}$ extension at $72^{\circ} \mathrm{C}$. A final extension of $7 \mathrm{~min}$ at $72^{\circ} \mathrm{C}$ was performed. Aliquots of $10 \mu \mathrm{L}$ of the PCR product were analysed by electrophoresis through a $1.2 \%$ agarose gel. A representative gel is given in Figure 2. PCR products were transferred into positively charged nitrocellulose membranes (Hybond $\mathrm{N}+$, Amersham) and fixed at $80^{\circ} \mathrm{C}$ for $2 \mathrm{~h}$. The membranes were hybridized under stringent conditions using HPV specific biotinylated probes as described previously [30]. The probes used in this study were MY14, WD74, WD126, MY16, MY115, MY70 and 
Table 4 Primers and specific probes used for HPV detection and typing

\begin{tabular}{|c|c|c|c|}
\hline \multicolumn{3}{|l|}{ Primers } & \multirow{2}{*}{$\begin{array}{l}\text { Sequence } \mathbf{5}^{\prime} \rightarrow \mathbf{3}^{\prime} \\
\text { CAA CTT CAT CCA CGT TCA CC }\end{array}$} \\
\hline \multirow[t]{2}{*}{ Primers for $\beta$-globin amplification } & & PC 04 & \\
\hline & & $\mathrm{GH} 20$ & GAA GAG CCA AGG ACA GGT AC \\
\hline \multirow[t]{2}{*}{ BZLF1 Primers for EBV amplification } & & ZES & GCC ACC TाT GCT ATC TाT GC \\
\hline & & ZEAS & AGG CGT GGT TTC AAT AAC GG \\
\hline \multirow[t]{2}{*}{ Primers for HPV amplification } & & \multirow{2}{*}{$\begin{array}{l}\text { MY } 09 \\
\text { MY } 11\end{array}$} & CGT CCM ARR GGA WAC TGA TC \\
\hline & & & GCM CAG GGW CAT AAY AAT GG \\
\hline & HPV 16 & MY14 & CAT ACA CCT CCA GCA CCT AA \\
\hline & HPV 18 & WD74 & GGA TGC TGC ACC GGC TGA \\
\hline & HPV 31 & WD126 & CAA AAG CCC AAG GAA GAT C \\
\hline \multirow[t]{4}{*}{ Specific probes for HPV typing } & HPV 33 & MY16 & CAC ACA AGT AAC TAG TGA CAG \\
\hline & HPV 35 & MY115 & CTG CTG TGT CTT CTA GTG ACA G \\
\hline & HPV 45 & MY70 & TAG TGG ACA CTA CCC GCA G \\
\hline & HPV 59 & MY123 & GCC AGT TAA ACA GGA CCC \\
\hline
\end{tabular}

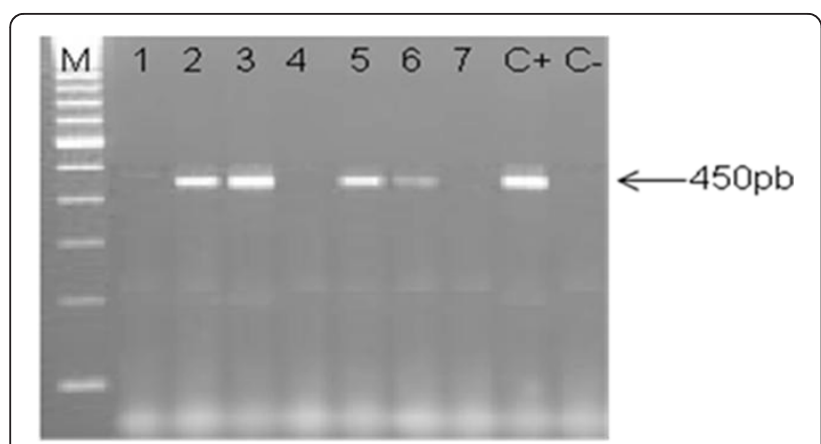

Figure 2 Representative illustration of HPV detection Electrophoresis gel photo (A). Lanes 2, 3, 5 and 6 correspond to HPV positive NPC specimens; Lanes 1, 4 and 7 correspond to HPV negative NPC specimens; C-: negative control (sterile distilled water); C+: Positive control (HPV 31 DNA isolated from cervical cancer specimen). M: 100 bp ladder molecular weight marker.

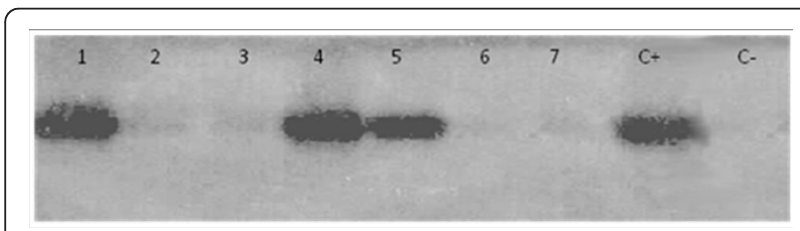

Figure 3 Example of hybridization photo illustrating HPV typing. Positive PCR products were hybridized with WD126 probe specific to HPV 31. Lanes 1,4 and 5 correspond to HPV 31 positive cases, whereas the others $(2,3,6$ and 7$)$ correspond to HPV 31 negative cases. C+: Positive control (HPV 31 DNA isolated from cervical cancer specimen), C-: negative control (sterile distilled water).
MY123 specific for HPV-16, 18, 31, 33, 35, 45 and 59 respectively (Table 4) [31]. Membranes were then washed under normal and stringent conditions. Specific hybrids were detected using a biotin luminescence detection kit (Biolabs, England) and the membranes were exposed for $30 \mathrm{~min}$ to X-ray film (Hyperfilm ECL, Amersham). An illustrative photo is given in Figure 3.

\section{Statistical analysis}

The results were analyzed statistically by the chi2 test. The level of significance was set at 95\% $(\alpha=0.05)$ for all tests.

\section{List of abbreviations}

NPC: Nasopharyngeal carcinoma; EBV: Epstein-Barr virus; HPV: Human papillomavirus; CC: Cervical cancer; ZEBRA: Z-Epstein-Barr Virus Replication Activator; WHO: World Health Organization.

\section{Acknowledgements}

We thank the medical staff at the Oncology center IBN Rochd, for their invaluable assistance in recruiting patients for the collection of specimens.

\section{Author details}

${ }^{1}$ Laboratory of Oncovirology, Institut Pasteur du Maroc, 1 Place Louis Pasteur, 20360 Casablanca, Morocco. 'Laboratory of Anthropogenetics and Physiopathology of Chouaîb Doukkali University, 299 Eljadida 24 000, Morocco. 'Biology and Medical Research Unit, Centre National de l'Energie, des Sciences et Techniques Nucléaires (CNESTEN), 10001 Rabat, Morocco. ${ }^{4}$ Faculty of Science Ain Chock Casablanca, Morocco. ${ }^{5}$ Service de Radiothérapie, Centre d'Oncologie IBN Rochd, Casablanca, Morocco.

\section{Authors' contributions}

$\mathrm{NL}$ : designed experiments, contributed and analyzed data, Carried out the molecular studies and drafted the manuscript. MA: designed the primers, the approach to validation, including the selection of appropriate materials and revised the manuscript. MK: participated in study design and performed the statistical analysis. FN: participated in PCR protocol design and performed the typing test. TM: participated in PCR protocol design and performed the typing test. RD: participated in PCR protocol design and performed the typing test. KB: Participated in the conception of the study and in its 
coordination. NB: Collected NPC specimens and carried out the anatomy pathology analyses. MEM: designed the laboratory procedures, coordinated the laboratory quality control and revised the manuscript. MK: Conceived the study, supervised this work, participated in its design and coordination, and revised the manuscript. All authors read and approved the final manuscript.

\section{Competing interests}

The authors declare that they have no competing interests.

Received: 12 November 2010 Accepted: 25 February 2011

Published: 25 February 2011

\section{References}

1. Parkin DM, Whelan SL, Ferlay J, Raymond L, Young J: Cancer incidence in five continents. In Scientific publications. Volume VII. Lyon: IARC; 1997, Nº 143.

2. Benider A, Sahraoui S, Acharki A, Samlali R, Kahlain A: Carcinomas of the nasopharynx in children, Analysis of 50 cases. Bull Cancer 1995, 82:155-161.

3. Chaouki N, El Gueddari B: Epidemiological descriptive approach of cancer in Morocco through the activity of the National Institute of Oncology: 1986-1987. Bull Cancer 1991, 78:603-609.

4. Hildesheim A, Levine PH: Etiology of nasopharyngeal carcinoma: a review. Epidemiol Rev 1993, 15(2):466-85.

5. Rickinson AB, Kieff E: Epstein - Barr virus. In Fields Virology. 3 edition. Edited by: Fields B.N, Knipe DM, Howley PM. Lippincott, Raven publishers, Philadelphia (PA); 1996:2397-446.

6. Punwaney R, Brandwein MS, Zhang DY, Urken ML, Cheng R, Park CS, Li HB, Li X: Human Papillomavirus may be common within nasopharyngeal carcinoma of Caucasian Americans: investigation of Epstein-Barr Virus and human papillomavirus in eastern and western nasopharyngeal carcinoma using ligation-dependant polymerase chain reaction. Head Neck 1999, 21(1):21-9.

7. Bosch FX, Manos MM, Munõz N, Sherman M, Jansen AM, Peto J, Schiffman MH, Moreno V, Kurman R, Shah KV: Prevalence of human papillomavirus in cervical cancer: a worldwide perspective. J Natl Cancer Inst 1995, 87:796-802.

8. Krishna S, James S, Sreelekha T, Kattoor J, Balaram P: Primary Nasopharyngeal Cancer of Indian Origin and the Viral Link - A Preliminary Study. Austral- Asian Journal of Cancer 2006, 5:241-252.

9. McGlennen RC: Human papillomavirus oncogenesis. Clin Lab Med 2000, 20:383-406.

10. Munõz N, Bosch X, De Sanjose S, Herrero R, Castellsague X, Shah KV, Snijders PJF, Meijer CJLM: Epidemiologic classification of human papillomavirus types associated with cervical cancer. N Engl J Med 2003, 348:518-527.

11. Al Moustafa AE, Chen D, Ghabreau L, Akil N: Association between human papillomavirus and Epstein-Barr virus infections in human oral carcinogenesis. Medical Hypotheses 2009, 73:184-186.

12. De Villiers EM, Sandstrom RE, Zur Hausen H, Buck CE: Presence of papillomavirus sequences in condylomatous lesions of the mamillae and in invasive carcinoma of the breast. Breast Cancer Res 2005, 7: R1-11.

13. Kreimer AR, Clifford GM, Boyle P, Franceschi S: Human papillomavirus types in head and neck squamous cell carcinomas worldwide: a systematic review. Cancer Epidemiol Biomark Prev 2005, 14:467-475.

14. Krishna SM, James S, Kattoor J, Balaram P: Human papilloma virus infection in Indian nasopharyngeal carcinomas in relation to the histology of tumour. Indian J Pathol Microbiol 2004, 47:181-185.

15. Tung YC, Lin KH, Chu PY, Hsu CC, Kuo WR: Detection of human papilloma virus and Epstein-Barr virus DNA in nasopharyngeal carcinoma by polymerase chain reaction. Kaohsiung J Med Sci 1999, 15:256-262.

16. Prayitno A: Cervical cancer with Human papilloma Virus and Epstein Barr Virus positive. J Carcinog 2006, 10:13-16.

17. Ritchie JM, Smith EM, Summersgill KF, Hoffman HT, Wang D, Klussmann JP, Turek LP, Haugen TH: Human papillomavirus infection as a prognostic factor in carcinomas of the oral cavity and oropharynx. Int J Cancer 2003, 104:336-344.

18. Bouda M, Gorgoulis VG, Kastrinakis NG, Giannoudis A, Tsoli E, DanassiAfentaki D, Foukas P, Kyroudi A, Laskaris G, Herrington CS, Kittas C: "High risk" HPV types are frequently detected in potentially malignant and malignant oral lesions, but not in normal oral mucosa. Mod Pathol 2000, 13:644-653.

19. Zhang Q, Gutsch D, Kenney S: Functional and physical interaction between p53 and BZLF1: implications for Epstein-Barr virus latency. Mol Cell Biol 1994, 14:1929-1938.

20. Lopez-Lizarraga E, Sanchez-Corona J, Montoya-Fuentes H, Bravo-Cuellar A Campollo-Rivas O, Lopez-Demerutis E, Morgan-Villela G, ArcauteVelazquez F, Monreal-Martinez JA, Troyo R: Human papillomavirus in tonsillar and nasopharyngeal carcinoma: isolation of HPV subtypes 31. Ear Nose Throat J 2000, 79:942-944.

21. Khair MM, Mzibri ME, Mhand RA, Benider A, Benchekroun N, Fahim EM, Benchekroun MN, Ennaji MM: Molecular detection and genotyping of human papillomavirus in cervical carcinoma biopsies in an area of high incidence of cancer from Moroccan women. J Med Virol 2009, 81:678-84.

22. Amrani M, Lalaoui K, El Mzibri M, Lazo P, Belabbas MA: Molecular detection of human papillomavirus in 594 uterine cervix samples from Moroccan women (147 biopsies and 447 swabs). J Clin Virol 2003, 27:286-95.

23. Mirzamani N, Salehian P, Farhadi M, Tehran EA: Detection of EBV and HPV in nasopharyngeal carcinoma by in situ hybridization. Exp Mol Pathol 2006, 81:231-234.

24. Quinlivan EB, Holley-Guthrie EA, Norris M, Gutsch D, Bachenheimer SL, Kenney SC: Direct BRLF1 binding is required for cooperative BZLF1/ BRLF1 activation of the Epstein-Barr virus early promoter, BMRF1. NuCl Acids Res 1993, 21:1999-2007.

25. Mauser A, Saito S, Appella E, Anderson CW, Seaman WT, Kenney S: The Epstein-Barr virus immediate-early protein BZLF1 regulates p53 function through multiple mechanisms. J Virol 2002, 76:12503-12512.

26. Dyson N, Howley PM, Münger K, Harlow E: The HPV 16 E7 oncoprotein is able to bind the retinoblastoma gene product. Science 1989, 243:934-937.

27. Levine $A: P 53$ protein and its interactions with the oncogene products of the small DNA tumor viruses. Virology 1990, 177:419-426.

28. Giovannelli L, Campisi G, Lama A, Giambalvo O, Osborn J, Margiotta V, Ammatuna P: Human papillomavirus DNA in oral mucosal lesions. J Infect Dis 2002, 185:833-836.

29. Bonnet M, Guinebretiere JC, Kremmer E, Grunewald V, Benhamou E, Contesso G, Joab I: Detection of Epstein - Barr virus in Invasive Breast Cancers. J Nat/ Cancer Inst 1999, 91:1376-1381.

30. Sambrook J, Fritsch EF, Maniatis T: Molecular Cloning: a Laboratory Manual. Cold Spring Harbor, NY: Cold Spring Harbor Laboratory; 21989.

31. Bauer HM, Greer CE, Manos MM: Determination of genital human papillomavirus infection by consensus PCR amplification. In Diagnostic Molecular Pathology: A Practical Approach. Volume II. Edited by: Herrington CS, McGee JO'D. Oxford Univ. Press, Oxford; 1992:131-152.

doi:10.1186/1750-9378-6-3

Cite this article as: Laantri et al:: Human papillomavirus detection in moroccan patients with nasopharyngeal carcinoma. Infectious Agents and Cancer 2011 6:3.

\section{Submit your next manuscript to BioMed Central and take full advantage of:}

- Convenient online submission

- Thorough peer review

- No space constraints or color figure charges

- Immediate publication on acceptance

- Inclusion in PubMed, CAS, Scopus and Google Scholar

- Research which is freely available for redistribution

Submit your manuscript at www.biomedcentral.com/submit
C Biomed Central 